\title{
ФОРМИРОВАНИЕ ОРГАНИЗАЦИОННОЙ КУЛЬТУРЫ КОРПОРАЦИЙ ОБОРОННЫХ ОТРАСЛЕЙ
}

\section{(c) 2018 Базадзе Наталья Григорьевна}

доктор экономических наук, профессор

профессор кафедры «Менеджмент и маркетинг высокотехнологичных отраслей промышленности» Московский авиационный институт (Национальный исследовательский университет)

125993, г. Москва, Волоколамское шоссе, 4

E-mail: n-bazadze@yandex.ru

Корпоративная культура в оборонных отраслях следует формировать и развивать, в первую очередь, в части культуры организации труда, организации производства и управления на более ранних этапах жизненного цикла человеческих ресурсов - этапах подготовки потенциального персонала.

Ключевые слова: корпоративные структуры, специфика оборонных отраслей, корпоративная культура, организационная культура, уровни проявления корпоративной культуры, формирование организационно-управленческих компетенций.

\section{1. Роль корпоративной культуры}

Корпоративные структуры современного оборонного комплекса России сформировались в результате реорганизации системы управления промышленностью и структуры управления тех производственных и научно-производственных объединений, которые создавались, в основном в 60-е годы прошлого столетия. Дальнейшее организационное преобразование шло за счет интегрирования и акционирования, создания корпоративных структур холдингового типа. Управление такими крупными структурами, которые в значительной своей части являются лидерами глобального рынка вооружений, перестраивалось с учетом мировых достижений менеджмента, к которым причисляют общую корпоративную культуру.

Формированию и развитию корпоративной культуры уделяют большое внимание именно в крупных структурах, как в России, так и за рубежом, как инструменту, позволяющему сохранить целостность корпоративного образования и узнаваемость бренда. Развитую корпоративную культуру как совокупность основополагающих ценностей, убеждений, социальных норм и уступок, разделяемых всеми членами социумной группы, принято относить к ключевым факторам успеха, поскольку она обеспечивает интеграцию и взаимодействие всех категорий персонала внутри корпорации. Эта совокупность основных ценностей и поведенческих норм, передаются всем поступившим на работу сотрудникам как правильные для данной структуры, как только начинающим свою производствен- ную карьеру выпускникам учебных заведений, так и специалистам и руководителям с наличием стажа работы.

\section{2. Процессы формирования корпора-} тивной культуры

Формирование ценностей и поведенческих норм, значимых для эффективной работы на оборонных предприятиях, весьма длительный процесс. Начальной точкой этого процесса являются жизненные ценности, формирующиеся у работников, как носителей корпоративной культуры, в подростковом возрасте, по утверждению социологов до 12 лет и культурные нормы, распространенные в регионе проживания. Далее они развиваются, трансформируются при все более разнообразной и масштабной социализации личности, встречая на своем жизненном пути все большее количество сообществ, оказывающих влияние на пересмотр отношения к себе и к системе взаимоотношений с другими. Во втором случае для трудоспособного населения значимы и, соответственно, могут различаться - системы взаимоотношений в рабочей (производственной) среде и системы взаимоотношений с близкими (большое число контактов) и малознакомыми (малое число контактов) людьми.

Сейчас на отечественных предприятиях оборонных отраслей работает значительная численность персонала, чьи жизненные ценности формировались в эпоху социализма. Молодые специалисты и рабочие, начинающие свою производственную карьеру родились в эпоху «дико- 
го рынка», что неизбежно оказало влияние на их ценностные установки.

Под влиянием почти трех десятилетий эпохи трансформации отечественной экономики, личные жизненные ценности работников старших возрастных категорий изменились в большей или меньшей степени, как по разным регионам, так и по разным профессиональным группам. Так, в отраслях реального сектора экономики, в частности в оборонных отраслях, сохранились ценностная ориентация на коллективизм. В отраслях финансового, торгово-посреднического секторов, сектора услуг - преобладает ориентация на индивидуальный профессиональный рост и вознаграждение. Весьма заметны эти различия для Москвы - сосредоточия финансовых потоков и регионов - производителей высокотехнологичной продукции.

Таким образом, в числе значимых факторов для формирования адекватной требованиям времени корпоративной культуры, следует выделить:

- соотношение различных возрастных групп среди персонала, жизненные ценности и поведенческие нормы которых формировались в разных экономических системах;

- различия и сходства национально-этнических норм и кодексов поведения у разных работников и на разных стадиях жизненного цикла у одного работника, например, на стадии подготовки и на стадии работы в регионах обучения и регионах трудоустройства.

\section{3. Специфика корпоративной культуры} отечественных оборонных отраслей

Среди специфических особенностей корпораций оборонных отраслей, отражающихся в корпоративной культуре:

1) большое разнообразие профессиональных категорий персонала, как следствие много передельного производства, подготовка которых ведется в разных регионах страны в различных учебных заведениях;

2) рост скорости обновления технической и инструментальной базы производства и управления с большим количеством используемых новых информационных технологий, быстрее осваиваемых молодым поколением;

3) наличие персонала разных возрастных категорий как следствие длинноциклового производства (длительного цикла изготовления продукции);
4) замкнутость контура управления, жесткие требования соблюдения дисциплины и режима;

5) широкий территориальный разброс структурных единиц в рамках федеральных границ и большое число кооперационных связей на территории страны и за рубежом.

Большая часть российских оборонных корпораций холдингового типа, где отдельные хозяйствующие субъекты или обособленные структурные подразделения (филиалы и представительства) территориально расположены в различных районах и регионах страны. Так, например холдинг «Вертолеты России» - один из лидеров глобального рынка вертолетостроения, включает в свой состав конструкторские бюро, производственные, авиаремонтные и сервисные компании, расположенными в разных Федеральных округах и краях страны. Головной офис и вертолетный завод имени Михаила Миля и находятся в Москве, другие - в Подмосковье, Татарстане, Бурятии, Башкортостане, Приморском крае, Пермском крае, Ростовской области Южного федерального округа. Создание единой корпоративной культуры таких структур - процесс длительный, должен начинаться в рамках подготовки потенциального персонала в профильных учебных дисциплинах при формировании не только профессиональных, но и личностно-деловых компетенций.

\section{4. Структура корпоративной культуры как объекта управления}

Проявления корпоративной культуры отмечаются на трех уровнях:

1. Внешний, как правило, визуальный - дизайн офисов, дресс-коды, сувенирная атрибутика, протоколы и церемонии. Эти признаки легко наблюдаемы.

2. Внутренний - поведенческий уровень. Здесь оцениваются поведенческие модели работников. Это более сложный объект для исследования, он может быть представлен двумя компонентами действиями работника и его реакцией.

Поведенческие модели - совокупность действий работника и его реакции на окружающую среду, условия процесса работы, поведения других людей внутри и вне его рабочей группы.

Для оценки поведенческих моделей и выделения базовых типов предлагается четырехоконная панель (рисунок Варианты поведенче- 
ских моделей в корпоративных структурах), где в качестве оценочных шкал выбираются эффективность действий работника в коллективном трудовом процессе, с минимальными суммарными затратами на производство продукции требуемого качества, и адекватность реакции работников, определяемую уровнем соответствия корпоративным нормам. Эффективные действия - действия, которые приводят к достижению поставленной работником (работнику) цели в заданные сроки с наименьшими затратами.

3. Глубинный - уровень убеждений - основополагающие ценности организации, которые разделяются всеми членами этого социума и повторяют базовые ценности основателей, владельцев или топ-менеджеров компании, формируется под влиянием национально-этнической культуры региона местонахождения компании и, как правило, религиозной культуры этого региона. Основу развития американской бизнес-культуры, которая является прототипом культуры взаимоотношений современной рыночной экономики, составляет протестантская этика. Российская федерация - многоконфессиональная страна, большая часть населения которой - православные христиане и мусульмане.

Внешний уровень - весьма актуален для коротких внешних контактов, весьма значим для репрезентативности корпорации высшим уровнем руководства. Поведенческий уровень весьма актуален для руководителей среднего и первичного звена, специалистов и рабочих для организации эффективной работы внутри контура управления предприятием, входящим в корпоративную структуру, и для корпорации в целом. Причем культура отдельной структурной единицы может представлять собой субкультуру, повторяющую нормы всей корпорации, но частично включающая и специфичные нормы, свойственные только этому предприятию, вследствие его роли в общей корпоративной структуре, его территориальному расположению и доминирующей национальной культуре, возрасту организации и преобладающей возрастной группе персонала. В данном контексте корпоративную культуру следует рассматривать как организационную культуру - культуру орга-

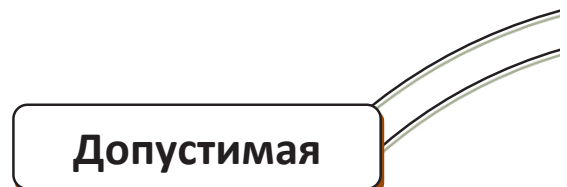
Оптимистичная
реакция, соответствующая
нормам компании при неоптимальных и нескоординированных действиях.

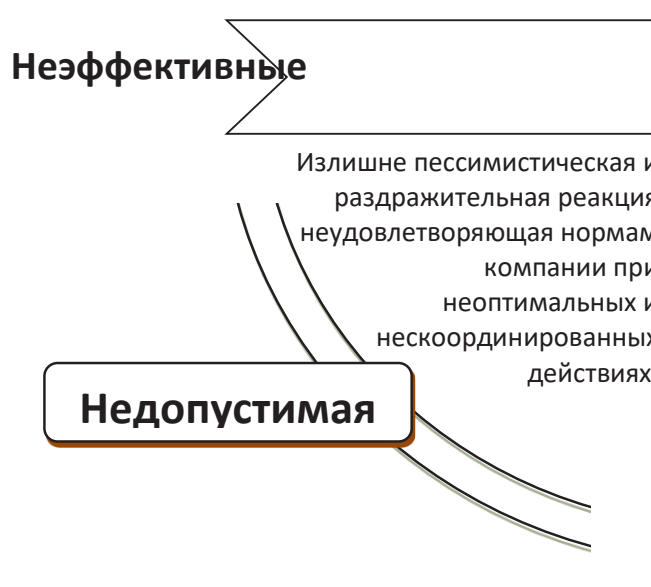

\section{Адекватная}

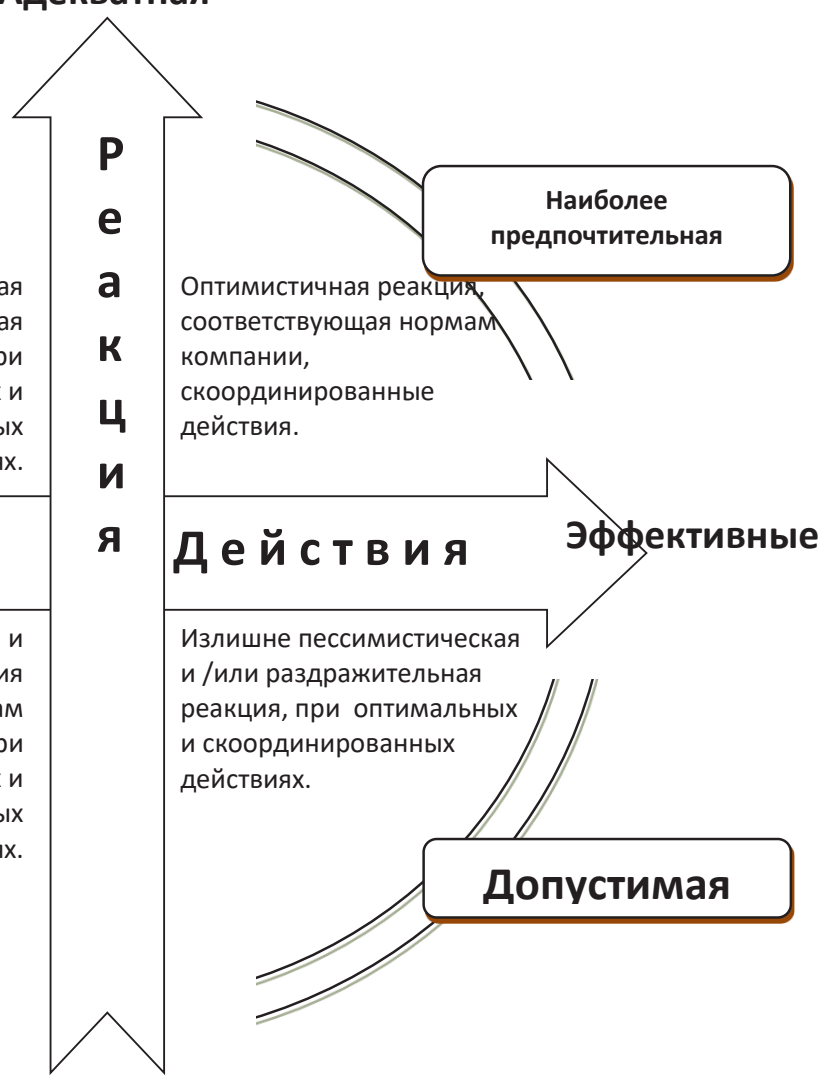

\section{Неадекватная}

Рис. Варианты поведенческих моделей в корпоративной культуре 
низации труда, организации производства, организации управления, включая и культуру организации рабочих мест.

Основание этой конструкции определяет надежность корпоративной культуры как инструмента управления. Поэтому перечень жизненных ценностей необходимо пополнять и пересматривать на этапе начала и прохождения трудового пути как начинающего работника (молодого рабочего и специалиста), так и на этапе действующего кадрового состава с высокой квалификацией.

На этом основании базируются такие востребованные в сегодняшней турбулентной экономике личностно-деловые компетенции как:

- физическая и психоэмоциональная работоспособность;

- эффективные межличностные коммуникации;

- работа в эффективной рабочей группе и команде;

- работа в мультизадачном режиме;

- скорость освоения нового, быстрая адаптация к изменениям.

\section{5. Заключение}

1. Корпоративная культура активно осваивается в оборонной отрасли на внешнем, представительском уровне. Пора осваивать более глубокие уровни - поведенческий и ценностный.

2. В корпоративную культуру следует вернуть организацию труда, производства и управлению, выстроенную на нормах работы с инновационными производственными и информационными технологиями.

3. Формирование и развитие личностно-деловых компетенций как процесс гораздо более продолжителен, чем процесс формирования отдельных профессиональных компетенций. Таким образом, действующие программы обучения необходимо дополнять новыми видами занятий междисциплинарного характера, предназначенных для выполнения рабочими группами разного уровня интегрирования трудового процесса - индивидуального, попарного, малой рабочей группой, большой рабочей группой в рамках одного и нескольких профилей (направлений подготовки).

\section{Библиографический список}

1. Адизес Ицхак. Размышления о менеджменте / Ицхак Адизес. Москва. 2011. 102 с.

2. Армстронг М. Практика управления человеческими ресурсами. 10-е издание. Пер. с англ/под ред. С.К. Мордовина. Санкт-Петербург. 2012. 848 с.

3. Базадзе Н.Г. Управление персоналомв сфере наукоемкого бизнеса. Учебное пособие. Москва. 2002. 248 с.

4. Базадзе Н.Г., Шеленкова Е.В. Проблемы развития компетенций по организационным коммуникациям для корпоративных структур авиастроительной отрасли // Электронный научный журнал «Труды МАИ». Выпуск № 59, 2012 г.

5. Гудкова, Т.В. Особенности корпоративной культуры российских компаний: моногр. Москва. 2016.168 с.

6. Гэлэгер Р. Душа организации. Как создать успешную корпоративную культуру. Москва. 2006. 352 с.

7. Лайкер Д. Корпоративная культура Тоуота. Уроки для других компаний. Москва. 2017. 385 с.

8. Емельянов, Ю.С. Человеческий капитал в модернизации России. Институциональный и корпоративный аспекты. Москва. 2014. 819 с. 